\title{
CREATIVE COMMONS LICENSE SEBAGAI HAK CIPTA INTERNASIONAL DITINJAU BERDASARKAN ASPEK HUKUM INDONESIA
}

\author{
Faisal \\ Fakultas Syari'ah Universitas Islam Negeri Raden Intan, Lampung, \\ Email : faisal@radenintan.ac.id \\ Dani Amran Hakim \\ Fakultas Syari'ah Universitas Islam Negeri Raden Intan, Lampung, \\ Email : daniamranhakim@ radenintan.ac.id
}

Is Susanto

Fakultas Ekonomi dan Bisnis Islam Universitas Islam Negeri Raden Intan,

Lampung,

Email : issusanto@radenintan.ac.id

\begin{abstract}
Abstrak
Perkembangan teknologi khususnya internet telah mempermudah masyarakat untuk mengakses dan mendistribusikan informasi. Namun, kegiatan seperti copy-cut-paste (menyalin-memotong-menempel), menyunting (editing) ataupun berbagi dokumen (file sharing) justru menimbulkan hal kontradiktif terhadap hukum hak cipta. Berdasarkan hal tersebut tahun 2002 sebuah organisasi nirlaba membuat inovasi dan terobosan yang memungkinkan berbagi dan menggunakan kreativitas dan pengetahuan melalui alat hukum gratis. Metode penelitian yang digunakan dalam tulisan ini adalah metode penelitian yuridis normatif dengan fokus pada pendekatan perundang-undangan dan analisis konten. Berdasarkan analisis pembahasan creative commons bukanlah alternatif dari hukum hak cipta, melainkan bekerja berdampingan dan mampu membuat pencipta/pemegang hak cipta memodifikasi haknya ke dalam keadaan yang paling sesuai dengan kebutuhan. Lisensi creative commons di Indonesia penggunaannya dimungkinkan menurut Pasal 9 ayat (1) Undang-Undang Nomor 28 Tahun 2014 tentang Hak Cipta. Lalu pemegang hak berdasarkan Pasal 81 UU Hak Cipta, dapat mengumumkan dan/atau berhak memberikan lisensi kepada pihak lain berdasarkan perjanjian lisensi untuk melaksanakan perbuatan sebagaimana dimaksud dalam Pasal 9 ayat (1), memperbanyak ciptaannya/produk hak terkaitnya dengan persyaratan tertentu. Selanjutnya berdasarkan Undang-Undang Nomor 11 Tahun 2008 tentang Informasi dan Transaksi Elektronik Pasal 1 ayat (5), kegiatan yang dilaksanakan oleh creative commons adalah kegiatan penyelenggaran sistem elektronik.
\end{abstract}


Kata Kunci: Creative Commons; Hak Cipta; Lisensi.

\section{Abstract}

The development of technology, especially the internet, has made it easier for people to access and distribute information. However, activities such as copy-cut-paste, editing or file sharing may actually harm the copyright law. Based on that, in 2002, a non-profit organization made a breakthrough innovation where it is possible to share and use creativity and knowledge through free legal tools. The research method used in this paper is a normative juridical research method with a focus on the statutory approach and content analysis. Based on the analysis of the discussion, creative commons is not an alternative to copyright law, but rather work side by side and is able to make the creator/copyright holder to modify their rights in the most appropriate circumstances. The use of creative commons licenses in Indonesia is possible according to Article 9 paragraph (1) of Law Number 28 of 2014 concerning Copyright. Furthermore, the rights holder, based on Article 81 of the Copyright Law, able to announce and/or has the right to grant license to other parties based on the license agreement to carry out the action referred to in Article 9 paragraph (1), reproduce their rightful works/products with certain conditions. Furthermore, based on Law Number 11 of 2008 concerning Electronic Information and Transactions Article 1 paragraph (5), the activities carried out by the creative commons are the activities of organizing an electronic system.

Keywords: Creative Commons; Copyright; License.

\section{PENDAHULUAN}

Kemajuan teknologi di Indonesia tentu memberikan perubahan yang sangat signifikan untuk masyarakat di Indonesia terutama penggunaannya, baik perubahan tersebut positif ataupun negatif. Pada dasarnya teknologi adalah hal yang penting bagi kehidupan karena hal tersebut mempermudah pengguna dalam mengerjakan sesuatu yang terbilang rumit. Maka dari itu perkembangan teknologi informasi dan komunikasi telah menjadi salah satu variabel dalam Undang-Undang Hak Cipta, ${ }^{1}$ mengingat teknologi informasi dan komunikasi di satu sisi memiliki peran strategis dalam pengembangan hak cipta, tetapi di sisi lain juga menjadi alat untuk pelanggaran hukum di bidang ini.

Pengaturan yang proporsional sangat diperlukan, agar fungsi positif dapat dioptimalkan dan dampak negatifnya dapat diminimalkan.

${ }^{1}$ Devega R. Kilanta, "Penegakan Hukum terhadap Hak Cipta Berdasarkan UndangUndang Nomor 28 Tahun 2014 tentang Hak Cipta." Lex Crimen, Volume 6 Nomor 3 Tahun 2017 
Perkembangan teknologi dan ekonomi kreatif yang menjadi salah satu andalan Indonesia dan berbagai negara dan berkembang pesatnya teknologi informasi dan komunikasi mengharuskan adanya pembaruan UndangUndang Hak Cipta, mengingat hak cipta menjadi basis terpenting dari ekonomi kreatif nasional. ${ }^{2}$

Suatu karya cipta (ciptaan) ketika diunggah ke internet, maka akan menjadi bagian dari pengetahuan umum dan terbuka bagi siapa saja untuk mereproduksi dan memodifikasinya. ${ }^{3}$ Ciptaan sebagai barang informasi (information goods) ${ }^{4}$ tentunya sangat potensial untuk digandakan dan disebarluaskan secara terus-menerus ke jutaan orang dalam waktu singkat. Hal ini dapat dimaklumi mengingat kemampuan teknologi digital ${ }^{5}$ untuk menduplikasi atau membuat salinan (copy) informasi dengan kualitas yang sama dengan aslinya tanpa merusak atau mengurangi sumber aslinya. Seiring dengan meningkatnya akses informasi dan interaksi di internet, maka hukum hak cipta semakin menjadi relevan terhadap lebih banyak orang dibandingkan dengan 60 tahun yang lalu sebelum kemunculan internet.

Hukum hak cipta pada mulanya dalam konteks teknologi pra-digital memang selaras jika dikondisikan untuk penggunaan secara manual terhadap ciptaan yang berbentuk fisik. Namun dalam konteks teknologi digital saat ini, akan menjadi semakin pelik ketika kegiatan seperti copy-cutpaste (menyalin-memotong-menempel), menyunting (editing) ataupun berbagi dokumen (file sharing) justru menimbulkan hal yang kontradiktif terhadap eksistensi hukum hak cipta. ${ }^{6}$ Pada gilirannya, keberadaan internet secara perlahan mendorong terjadinya pergeseran paradigma terhadap apa yang dapat dilindungi oleh hak cipta. Di sisi lain, kemunculan internet

${ }^{2}$ Lihat Penjelasan Umum Paragraf Pertama dan Kedua Undang-Undang Nomor 28 Tahun 2014 tentang Hak Cipta

${ }^{3}$ Volker Grassmuck, "Towards a New Social Contract: Free-Licensing into the Knowledge Commons," dalam Lucie Guibault dan Christina Angelopoulos, Ed., Open Content Licensing: from Theory to Practice, (Amsterdam: Amsterdam University Press, 2011) h. 21.

4 Carl Shapiro dan Han Ronald Varian, A Strategic Guide to the Network Economy, (Boston: Harvard Business School Press, 1999) h. 3.

${ }^{5}$ Edmon Makarim, Kompilasi Hukum Telematika, (Jakarta: P.T. Raja Grafindo Persada, 2004) h. 37

${ }^{6}$ Neil Weinstock Netanel, Copyright's Paradox, (New York: Oxford University Press, 2008) h. 8 
ternyata memungkinkan bertumbuhnya budaya berbagi (culture of sharing) ${ }^{7}$ yang memudahkan pencipta menyebarluaskan ciptaannya.

Kreatifitas manusia atas karya ciptanya yang memiliki nilai ekonomis telah menciptakan sebuah industri baru, yaitu industri kreatif. Industri kreatif sangat tergantung dengan hak cipta sebagai jaminan hukum atas hasil cipta yang memiliki nilai ekonomis. Nilai ekonomis atas karya inilah yang menjadi pemicu terjadinya pelanggaran hak cipta. ${ }^{8}$ Implikasi dari perkembangan internet adalah dampaknya yang amat besar bagi kegiatan ekonomi yang menjadi semakin efisien, namun dari segi hukum kemajuan teknologi internet kerap memunculkan permasalahanpermasalahan baru. Kemunculan sistem peer to peer $(\mathrm{P} 2 \mathrm{P})$, mesin pencarian (search engine), buku elektronik (e-books), kompresi audio-video dalam berbagai format (mp3, audio atau flv video) yang memungkinkan ditampilkan dalam laman web adalah contoh dari inovasi yang memiliki nilai ekonomis dalam kehidupan manusia, namun memiliki dampak besar dalam segi hukum pada umumnya dan hak cipta pada khususnya.

Hak cipta atau copy right berfungsi untuk menyatakan bahwa suatu karya merupakan ciptaan dan/atau milik suatu pihak. Dengan menggunakan hak cipta, pencipta juga dapat melindungi karyanya. Karya yang dilindungi hak cipta tidak boleh disebarluaskan untuk berbagai kepentingan, baik yang bertujuan komersil ataupun non komersil jika tanpa sepengetahuan penciptanya, bahkan yang melanggarnya akan dikenakan hukuman. Ada juga yang menganggap bahwa hak cipta menghambat kreativitas dan memperlambat penyebaran karya cipta. Ditambah lagi adanya aturan mengenai pendaftaran lisensi hak cipta. Tidak sedikit muncul pendapat yang mengatakan bahwa proses pendaftaran hak cipta untuk suatu karya terlalu berbelit-belit dan memerlukan biaya yang mahal. Hak Cipta hanya cocok untuk karya-karya yang ditujukan untuk objek yang dikomersilkan. Budaya kerjasama dan kebersamaan pun hilang, digantikan oleh budaya korporat kapitalis. ${ }^{9}$

Berdasarkan hal tersebut, untuk mengakomodasi solusi di atas, Tahun 2002 yang lalu sebuah organisasi nirlaba membuat inovasi dan terobosan terbaru yang memungkinkan berbagi dan menggunakan

7 Alexandra Crosby dan Ferdiansyah Thajib, "A Culture of Sharing," Inside Indonesia, September 2011, http://www.insideindonesia.org/weeklyarticles/a-culture-ofsharing

${ }^{8}$ Riko Sulung Raharjo, M. Khoidin, and Fahamsyah Ermansyah. "Perlindungan Hukum terhadap Pencipta atas Pencatatan Suatu Ciptaan yang Sama." Jurnal Lentera Hukum, Volume 5 Nomor 3 Tahun 2018, h. 437-456.

9 Kusuma Prasetyo Putro. "Creative Commons Lisence sebagai Alternatif Perlindungan Karya Cipta Musik di Era Digital”. Makalah, h. 2 
kreativitas dan pengetahuan melalui alat hukum gratis. Gratis memiliki arti mudah menggunakan lisensi hak cipta menyediakan cara sederhana, standar untuk memberikan izin publik untuk berbagi dan menggunakan karya kreatif pencipta karya. Creative Commons License (atau Lisensi Kreativitas Bersama selanjutnya disingkat Lisensi CC) adalah terobosan yang dibuat organisasi nirlaba untuk dunia maya. ${ }^{10}$ Creative Commons memberi kebebasan kepada para kreator untuk saling berbagi ide dan karya, dengan terbuktinya bahwa creative commons berkontribusi pada pertumbuhan produk budaya yang bermanfaat bagi tiap orang. Creative Commons memperkenalkan Lisensi Kreativitas Bersama (Creative Commons License) sebagai perjanjian lisensi hak cipta di internet.

\section{METODE PENELITIAN}

Metode penelitian yang digunakan dalam tulisan ini adalah metode penelitian yuridis normatif dengan fokus pada pendekatan perundangundangan (statute approach) dan analisis konten. Menurut Soerjono Soekanto penelitian yuridis normatif adalah penelitian hukum kepustakaan. ${ }^{11}$ Spesifikasi penelitian dalam penulisan ini adalah deskriptifanalitis, artinya bahwa penelitian ini termasuk lingkup penelitian yang menggambarkan, menelaah dan menjelaskan secara tepat serta menganalisa aspek hukum creative commons license di Indonesia.

\section{PEMBAHASAN}

\section{Ruang Lingkup dan Konsepsi Creative Commons License (Lisensi Kreativitas Bersama)}

Organisasi Creative Commons didirikan oleh Lawrence Lessig dengan dukungan rekan-rekannya dari Centre for the Public Domain pada tahun 2001. Creative Commons adalah organisasi no-profit yang yang dibentuk untuk menjembatani dua paham yang saling bertentangan. Paham pertama terbentuk dari $R O$ Culture yang mengatur secara ketat penggunaan karya cipta "all rights reserved" dan paham yang kedua mewakili $R W$ Culture yang penuh dengan kebebasan berkreasi "no rights reserverd". Creative Commons hadir sebagai penengah dari kedua paham tersebut dengan "some rights reserved"12 bukan sebagai sebuah sarana yang

\footnotetext{
${ }^{10} \mathrm{http} / / /$ creativecommons.org/about

${ }^{11}$ Soerjono Soekanto, Penelitian Hukum Normatif, (Jakarta: Rajawali Pers, 2006)
} h. 14

12 "Some Rights Reserved": Building a Layer Reasonable Copyright $\mathrm{http} / /$ creativecommons.org/History 
menyerang hak cipta namun menjadikan hak cipta sebagai sarana untuk mendukung public domain. ${ }^{13}$

Creative Commons berkedudukan di California, Amerika Serikat, yang menyediakan serangkaian lisensi hak cipta yang terstandarisasi dan dapat dimanfaatkan pencipta sebagai media penyebarluasan ciptaan. ${ }^{14}$ Pencipta sebagai pemberi lisensi memberikan izin kepada publik sebagai penerima lisensi melalui lisensi Creative Commons (lisensi CC) untuk menggunakan ciptaannya secara bebas dan legal dengan penyerahan sebagian dari hak cipta yang dimilikinya seraya mempertahankan hak-hak yang lain (some rights reserved).

Creative Commons memiliki 4 (empat) kondisi utama yang ditawarkan kepada pencipta atas karya cipta mereka, yaitu: ${ }^{15}$

1) Attribution, pencipta mewajibkan adanya atribusi/pencantuman namanya sebagai pencipta bagi mereka yang menggunakan karya kreatifnya;

2) Non-Comercial, pencipta hanya mengijinkan penggunaan non komersial atas karyanya;

3) No Derivatives, pencipta mewajibkan penggunaan karyanya sebagaimana adanya, tidak untuk dimodifikasi; dan

4) Share Alike, setiap derivatif atau turunan dari karya yang digunakan harus diumumkan dengan sebuah lisensi share alike license.

Berdasarkan ke-empat kondisi utama tersebut, lahirlah 6 (enam) variasi lisensi Creative Commons, yaitu: 1) Attribution (CC BY); 2) Attribution-Share Alike (CC BY-SA); 3) Attribution-No Derivatives (CC BY-ND): 4) Attribution-Non Commercial (CC BY-NC); 5) Attribution-Non Commercial-No Derivatives (CC BY-NC-ND); dan (5) Attribution-Non Commercial-ShareAlike (CC BY-NC-SA). ${ }^{16}$

Pilihan tersebut ditambahkan "basic template license". Template tersebut menjamin bahwa "creator" 1) Pencipta menguasai penuh hak cipta atas hasil karyanya; 2) Menegaskan bahwa setiap penggunaan yang wajar "fair use", penjualan pertama "fair sale", hak kebebasan berekspresi yang tidak dibuat-buat oleh lisensi CC; serta 3) Selama pengguna menghormati kondisi yang telah ditentukan oleh pencipta "creator", lisensi memberikan

${ }^{13}$ Lawrence Lessig CC in Review: Lawrence Lessig on Supporting the Commons $\mathrm{http} / /$ creativecommons.org/weblog/entry/5561

${ }^{14} \mathrm{http} / / /$ creativecommons.org/about $O p$., Cit.

${ }^{15}$ Lawrence Lessig, Budaya Bebas: Bagaimana Media Besar Memakai Teknologi dan Hukum untuk Membatasi Budaya dan Mengontrol Kreativitas, (Yogyakarta: KUNCI Cultural Studies Center, 2004) h. 73

${ }^{16}$ Ibid., h. 74 
setiap orang dengan empat kebebasan. Menggandakan pekerjaan "to copy the work", membagikan pekerjaan "to distribute the work". Lisensi juga membutuhkan pengguna untuk (1) mendapatkan izin untuk penggunaan diluar dari yang dizinkan, (2) mempertahankan pemberitahuan hak cipta secara utuh, (3) terhubung kepada lisensi, (4) tidak mengubah jangka waktu lisensi, dan (5) tidak menggunakan teknologi untuk membatasi hak lisensinya dibawah lisensi creative commons. ${ }^{17}$

\section{Lisensi Creative Commons Berdasarkan Aspek Hukum Indonesia \\ 1) Lisensi Creative Commons dalam Perspektif Hukum Hak Cipta}

Peraturan perundang-undang mengenai hak cipta memberikan jalan kepada pemilik karya cipta yang merasa hak ciptanya dilanggar untuk menempuh upaya hukum secara perdata atau pidana. Namun, apabila pemegang karya cipta memilih upaya hukum tersebut tentu saja harus mau menanggung konsekuensinya. Dalam hal ini harus siap menyediakan waktu, tenaga dan biaya untuk menjalani proses hukum tersebut. Untuk itu perlu dipertimbangkan matang-matang untung ruginya menempuh upaya hukum tersebut.

Peraturan perundang-undangan hak cipta juga membuka peluang adanya penyelesaian melalui arbitrase atau alternatif penyelesaian sengketa. ${ }^{18}$ Namun, hal itu harus disepakati terlebih dahulu oleh kedua belah pihak. Biasanya, telah ada perjanjian terlebih dahulu mengenai pengumuman dan/atau perbanyakan suatu karya cipta, termasuk mengenai pilihan penyelesaian apabila terjadi sengketa.

Berdasarkan dengan fakta yang ada, ternyata cara paling efektif adalah dengan memberikan sanksi sosial kepada pelanggar hak cipta tersebut. Disadari atau tidak, komunitas pengguna internet kian hari kian bertambah besar. Jaringan internet juga semakin luas. Ini memudahkan penyebarluasan informasi apabila ada pihak yang bertindak tidak fair terhadap suatu karya cipta, termasuk melanggar hak cipta tersebut. Dengan kekuatan jaringan internet tersebut pihak yang melakukan pelanggaran tersebut dapat diberikan sanksi sosial berupa pengucilan atau dimasukkan dalam daftar hitam pihak-pihak yang tidak akan diajak kerjasama dalam kegiatan apapun (black list).

Disamping itu, beberapa penyedia layanan blog gratis ataupun situssitus pertemanan/sosial telah membuat ketentuan yang jelas dan tegas tentang perbuatan yang melanggar hak cipta tersebut. Ketentuan itu

${ }^{17}$ Ibid., h. 75

${ }^{18}$ Dewi Sulistianingsih dan Muhammad Shidqon Prabowo. "Problematik Dan Karakteristik Penyelesaian Sengketa Kekayaan Intelektual Melalui Badan Arbitrase Nasional Indonesia." QISTIE: Jurnal Ilmu Hukum, Volume 12 Nomor 2, Tahun 2019, h. $166-177$ 
biasanya memberikan hak kepada penyedia layanan untuk melakukan tindakan tegas terhadap pengguna layanan yang melanggar hak cipta, dengan atau tanpa adanya laporan dari pihak lain.

Dengan melihat kekosongan suatu peraturan yang mengatur mengenai hak cipta maka konsep lisensi Creative Commons yang sejak tanggal 16 Desember 2002 sudah mulai dipromosikan oleh sebuah organisasi non-profit di Amerika Serikat. Pada dasarnya, lisensi Creative Commons ini membantu pemilik karya cipta untuk menyatakan sikapnya atas penggunaan hak cipta yang dimilikinya. ${ }^{19}$

Apabila seseorang mem-posting karya ciptanya di internet, maka secara hukum setiap orang harus tahu bahwa karya cipta itu dilindungi hak cipta. Dengan begitu, tidak boleh ada orang yang memperbanyak atau mencantumkan karya cipta itu tanpa seizin pemiliknya. Namun, mungkin saja pemilik hak cipta tersebut sebenarnya membolehkan orang lain memperbanyak karya ciptanya dengan syarat namanya tetap dicantumkan pada karya cipta itu. Tanpa ada pernyataan sikap yang jelas, orang lain tidak akan mengetahui hal itu. ${ }^{20}$

Lisensi Creative Commons memberikan kemudahan bagi seseorang untuk menyatakan sikapnya tersebut. Seseorang yang mempunyai karya cipta dapat mendaftarkan karya ciptanya tersebut ke lisensi Creative Commons dan diberikan suatu simbol oleh lisensi Creative Commons, ${ }^{21}$ simbol-simbol itu berlaku dan dipahami secara universal di negara-negara yang menerapkannya. Sama seperti rambu-rambu lalu lintas yang pada umumnya sama di berbagai negara dan dipahami secara universal.

Lisensi creative commons meningkatkan transparansi dan kepastian hukum bagi para pengguna ciptaan dan pemegang hak cipta. Hak cipta adalah masalah yang kompleks, Seseorang yang awam mengenai hukum hampir tidak dapat mengetahui hal apa yang harus dimiliki agar sebuah ciptaan dapat digandakan secara sah untuk penggunaan pribadi, digunakan untuk tujuan pendidikan, atau dikutip. Sebaliknya, lisensi kreativitas bersama, misalnya lisensi creative commons, menawarkan penjelasan dalam bahasa yang sederhana untuk menginformasikan penerima lisensi mengenai apa yang bisa mereka lakukan terhadap sebuah ciptaan, kewajiban yang harus mereka patuhi, dan hal apa saja yang tidak dapat mereka lakukan terhadap ciptaan tersebut. Penjelasan ini juga menguntungkan bagi pemberi lisensi, yang umumnya bukan ahli hukum (terutama jika pemberi lisensi adalah pencipta dari ciptaan itu sendiri) dan dengan cara ini dapat

\footnotetext{
${ }^{19} \mathrm{https}: / /$ creativecommons.org/licenses/by-nc-sa/4.0/legalcode.id

${ }^{20} \mathrm{Ibid}$.

${ }^{21}$ Ibid.
} 
memperoleh semua informasi yang diperlukan mengenai aturan untuk menggunakan sebuah ciptaan.

Keuntungan penting lainnya yang diperoleh dari lisensi creative commons adalah penyederhanaan hubungan hukum antara pemegang hak cipta dan pengguna ciptaan. Lisensi creative commons adalah alat yang terstandarisasi yang membuat hubungan hukum tersebut menjadi sederhana bagi kedua belah pihak. Penyusunan dan negosiasi kontrak lisensi individu adalah masalah yang rumit yang biasanya membutuhkan keterlibatan pengacara. Menyumbangkan ciptaan berhak cipta ke dalam wadah kepemilikan bersama dalam lingkungan internasional (melalui internet) bahkan lebih rumit lagi. Lisensi kreativitas bersama membebaskan para pencipta dan pemegang hak cipta dari kerumitan ini. Khususnya, teks lisensi yang disebarluaskan oleh inisiatif seperti creative commons secara menyeluruh disusun oleh para ahli hukum dan kemudian dapat diakses secara gratis untuk penggunaan pihak yang berkepentingan.

Permasalahan hak cipta di Indonesia diatur dalam Undang-Undang Nomor 28 Tahun 2014 tentang Hak Cipta (UU Hak Cipta). Dalam undangundang tersebut, berdasarkan Pasal 1 angka 1 pengertian hak cipta adalah "hak eksklusif bagi pencipta atau penerima hak untuk mengumumkan atau memperbanyak ciptaannya atau memberikan izin untuk itu dengan tidak mengurangi pembatasan-pembatasan menurut peraturan perundangundangan yang berlaku.

Sistem hukum hak cipta di Indonesia berdasarkan UU Hak Cipta maka bisa dilihat bahwa konsep yang diusung oleh creative commons belum mendapat tempat yang signifikan di dalam sistem hukum hak cipta di Indonesia. ${ }^{22}$ Hal ini ditandai dengan minimnya penjabaran dan juga pengimplementasian konsep-konsep dan ide-ide dasar dari creative commons.

Belum masuknya konsepsi creative commons di dalam sistem hukum hak cipta di Indonesia bisa diakibatkan oleh masa kemunculan dan perkembangan dari creative commons sendiri. Inisiatif untuk membentuk creative commons sendiri baru muncul di awal tahun 2000-an tepatnya tahun 2002 dan tumbuhnya pun di luar negeri bukan di Indonesia. ${ }^{23}$ Konsep creative commons tidak serta merta menjadi besar dan terkenal seperti sekarang melainkan memerlukan waktu yang cukup lama untuk bisa tumbuh dan berkembang seperti sekarang ini. Hal ini dikarenakan menurut peneliti akibat berbedanya konsep perlindungan pencipta karya cipta yang ditawarkan oleh creative commons jika dibandingkan dengan perlindungan

$$
\text { 2001) h. } 35 \text { Ibid., h. } 37
$$

${ }^{22}$ Gunawan Wijaya, Lisensi (Seri Hukum Bisnis), (Jakarta: Raja Grafindo Persada, 
hukum yang konvensional. ${ }^{24}$

Indonesia sebagai negara berkembang memerlukan inovasi-inovasi untuk terus melangkah menuju cita-cita menjadi negara maju. Salah satunya adalah melalui pengembangan industri kreatif yang mana hak cipta menjadi salah satu tiang penyangganya, yang bisa mendorong atau malah bisa menghambat perkembangan dari industri itu sendiri. Dengan adanya konsep yang ditawarkan creative commons diharapkan bisa memberikan perubahan atau bahkan mendorong kemajuan industri kreatif Indonesia. Setiap orang bisa menggunakan karya cipta orang lain selama memang diperbolehkan tanpa ada rasa takut disebut menjiplak dan dikenai gugatan perdata, hal ini lah yang bisa mendorong perkembangan dan kemajuan yang diharapkan sehingga sangat penting konsep creative commons ini untuk bisa dimasukkan kedalam undang-undang.

Patut digarisbawahi bahwa creative commons bukanlah jalan alternatif dari hukum hak cipta, melainkan bekerja berdampingan dengan hukum hak cipta dan mampu membuat pencipta/pemegang hak cipta memodifikasi haknya ke dalam keadaan yang paling sesuai dengan kebutuhan. Oleh karena hak eksklusif hanya dilisensikan sebagian dan di bawah syarat-syarat tertentu, pengguna yang melanggar lisensi, berarti juga melanggar UU Hak Cipta. ${ }^{25}$

Karya cipta termasuk ke dalam salah satu ciptaan yang dilindungi. Pasal 40 UU Hak Cipta tentang 'ciptaan yang dilindungi' tidak menyebut secara eksplisit, tetapi penjelasan atas pasal ini menyebutkan: "Ciptaan yang belum diumumkan, sebagai contoh sketsa, manuskrip, cetak biru (blue print), dan yang sejenisnya dianggap ciptaan yang sudah merupakan suatu kesatuan yang lengkap, mengacu pada UU Hak Cipta, tiga kemungkinan situasi atas akses terhadap konten digital karya cipta dapat diidentifikasikan sebagai berikut:

1) Hak cipta dipegang oleh negara.

Kondisi ini adalah kondisi yang paling mungkin terjadi jika didasarkan pada UU Hak Cipta di Indonesia. Berdasarkan undangundang tersebut karya cipta dapat dikelompokkan sebagai suatu karya yang harus dilindungi, sehingga hak cipta atas suatu karya cipta dipegang oleh negara, termasuk isi (kandungan) seperti cerita, babad, hikayat, dan lain-lain. Kondisi ini juga berlaku bagi ciptaan (yaitu teks dalam naskah) yang tidak diketahui penciptanya atau anonim. Pasal 39 ayat 1 UU Hak Cipta memberikan penjelasan lebih

${ }^{24}$ M.Ahmad Ramli, Cyber Law dan HAKI Dalam Sistem Hukum Indonesia, (Bandung: PT Refika Aditama, 2006) h. 78

${ }^{25}$ Aditia Gunawan, "Creative Commons: Penerapannya di Indonesia", Konferensi Perpustakaan Digital Indonesia, Jakarta, Makalah 2013, h. 4 
lanjut terkait masalah tersebut: "Jika suatu Ciptaan tidak diketahui Penciptanya dan Ciptaan itu belum diterbitkan, Negara memegang Hak Cipta atas Ciptaan tersebut untuk kepentingan Penciptanya." Menggunakan lisensi creative commons dalam pemberian ijin-ijin tertentu akan membantu institusi bekerja secara efektif sebab proses tersebut dilakukan bukan berdasarkan permintaan, melainkan berdasarkan bahan yang telah melalui proses verifikasi dan penentuan hak akses. Tingkat keteraksesan masyarakat terhadap suatu karya cipta yang sudah populer, dapat dijadikan landasan dalam menentukan prioritas. Karya cipta yang disajikan secara online membuat masyarakat benar-benar dapat melihat keindahan bentuk, warna, tulisan dari karya-karya asli itu. Dengan dikenal luasnya karya cipta oleh masyarakat, maka ancaman-ancaman pihak yang tidak bertanggung jawab (persoalan saling klaim) dapat dicermati, bukan hanya oleh institusi yang bersangkutan, tetapi oleh seluruh masyarakat Indonesia.

2) Hak cipta dipegang oleh pemilik hak cipta.

Kondisi ini dinyatakan dalam Undang-undang Hak Cipta Pasal 19 ayat 1, yang menyatakan bahwa "Hak Cipta yang dimiliki oleh Pencipta, yang setelah Penciptanya meninggal dunia, menjadi milik ahli warisnya atau milik penerima wasiat, dan Hak Cipta tersebut tidak dapat disita, kecuali jika hak itu diperoleh secara melawan hukum." Menurut UU hak cipta, yang dimaksud pengarang asli adalah orang yang namanya disebut dalam Ciptaan atau diumumkan sebagai Pencipta pada suatu Ciptaan. Meski tampak jelas, kondisi ini pun harus dicermati secara hati-hati, karena dalam dunia hak cipta seringkali sulit untuk membedakan apakah nama seseorang yang tercantum pada naskah adalah penulis (pencipta) atau penyalin. Meski negara memegang hak cipta atas karya seperti ini, Hak Moral pada Pencipta atau ahli waris (jika ada) tetap melekat dan tidak dapat disita. Dalam situasi ini lembaga pengelola yang memiliki tanggung jawab memperluas akses untuk masyarakat umum berperan penting sebagai mediator antara pemilik hak cipta dan pengguna. Sangat mungkin lisensi creative commons menjadi alat dalam negosiasi itu. Dalam kasus seperti ini, pilihan lisensi creative commons yang akan digunakan dapat disesuaikan sesuai dengan keperluan dan kesepakatan antara lembaga pengelola naskah dan pencipta/ahli waris.

3) Pemegang hak cipta atas ciptaan yang tidak jelas.

Kondisi ini bisa saja terjadi dalam suatu karya hak cipta. Kita tidak bisa menentukan siapa pemilik hak cipta ini meski sudah berusaha 
keras mencari. Ciptaan ini biasa disebut sebagai 'karya yatim' (orphan works). Bahan-bahan sejenis ini sesungguhnya berada di luar jangkauan keteraksesan baik oleh lembaga pemerintah maupun privat, sebab masih menyimpan kemungkinan ahli waris yang sah dari pemegang hak cipta tidak ingin haknya dieksploitasi. Berdasarkan regulasi di Indonesia, Negara memegang hak cipta atas situasi ini untuk kepentingan penciptanya. Lisensi creative commons bisa digunakan oleh lembaga pengelola naskah untuk memancing perhatian dan interaksi publik atas karya yatim ini dengan harapan pemilik sah dari karya bisa ditemukan. Selain mempertimbangkan kemungkinan-kemungkinan situasi di atas, pemilihan jenis lisensi creative commons yang akan digunakan sebaiknya juga disesuaikan dengan karakteristik lembaga pengelola. Baik perpustakaan maupun museum merupakan lembaga pendidikan dan budaya, dan jauh dari kesan komersial. Karena itu, upaya perluasan akses dilaksanakan untuk menunjang perkembangan ilmu pengetahuan dan budaya melalui berbagai macam kegiatan penelitian, bukan untuk tujuan komersial. Lisensi creative commons dapat menjadi pilihan bagi lembaga seperti perpustakaan dan museum. Meski demikian, sifat komersial tidak selamanya negatif. Pemberian lisensi yang membebaskan pengguna memanfaatkan konten digital untuk kepentingan komersial mungkin akan meningkatkan gairah di bidang industri kreatif di Indonesia, dengan catatan, pengguna yang memanfaatkannya berasal dari Indonesia. Jika hal tersebut belum dapat diterapkan, paling tidak pelaku industri kreatif, seniman, penulis, arsitek, dokter, dan berbagai profesi lain bisa mengambil inspirasi dari konten-konten digital untuk dijadikan karya kreatifnya sendiri

Dalam sistem hukum hak cipta yang ada saat ini, perlindungan terhadap suatu ciptaan diberikan secara otomatis sejak karya cipta tersebut lahir dalam bentuknya yang nyata dengan didaftarkan dalam lisensi creative commons. Perlindungan tersebut berupa hak eksklusif di mana seseorang yang membutuhkan karya cipta memiliki hak untuk mengumumkan atau memperbanyak ciptaannya, yang mana hak eksklusif itu sendiri memiliki arti bahwa hak tersebut semata-mata diperuntukkan bagi kepentingan kepada pengguna hak cipta. ${ }^{26}$

Menurut Lawrence Lessig, sistem hukum hak cipta yang demikian telah membentuk "budaya izin", yang berarti budaya lisensi creative commons, di mana untuk beberapa hal kita tidak perlu menghubungi pemilik

${ }^{26}$ Lawrence Lessig, The Future of Ideas, (New York: Random House, 2001) h. 3 
hak cipta terlebih dahulu sebelum mengunakan karyanya tersebut. Hukum pun menjadi efisien dan biaya transaksi yang dibutuhkan dalam "budaya izin" tidaklah mahal bahkan geratis serta creative commons juga dapat meningkatkan visibilitas pilihan hak cipta di internet yang akan membuat orang dapat dengan mudah menemukan hak cipta karya yang mereka gunakan. ${ }^{27}$

Dalam pola lisensi Creative Commons, terdapat beberapa upaya hukum dasar yang dapat dikombinasikan sehingga pencipta dapat memodifikasi istilah hak cipta dari "seluruh hak dilindungi" menjadi "beberapa hak dilindungi". Kombinasi dari upaya hukum tersebut kemudian terwujud dalam ragam lisensi, yang pada dasarnya memiliki tujuan untuk:

1) Membantu orang-orang yang ingin mendorong penggunaan ulang ciptaan mereka dengan menawarkan penggunaan ciptaan tersebut dibawah persyaratan yang dikeluarkan oleh lisensi creative commons dan terstandarisasi.

2) Membantu orang-orang yang ingin menggunakan ciptaan secara kreatif.

3) Membantu orang-orang yang ingin memperoleh hak atas karya ciptanya tersebut.

Lisensi Creative Commons di Indonesia penggunaannya dimungkinkan menurut Pasal 9 UU Hak Cipta. Dalam pasal tersebut, disebutkan bahwa Pemegang Hak berdasarkan Pasal 81 UU Hak Cipta, yaitu izin untuk mengumumkan dan/atau Cipta berhak memberikan lisensi kepada pihak lain berdasarkan perjanjian lisensi untuk melaksanakan perbuatan sebagaimana dimaksud dalam Pasal memperbanyak ciptaannya/produk hak terkaitnya dengan persyaratan tertentu. ${ }^{28}$

2) Creative Commons License Ditinjau Berdasarkan UndangUndang Informasi Transaksi Elektronik

Keberadaan creative commons Indonesia untuk dapat menjadi anggota afiliasi creative commons international (CCi) melalui beberapa tahap. Pertama, lembaga afiliasi creative commons di Indonesia yaitu Wikimedia Indonesia ${ }^{29}$ dengan pimpinan proyek (Pimpro) Publik Ivan Lanin dan Pimpro Legal Ari Juliano Gema menandatangani nota kesepahamaan dengan CCi pada bulan Desember 2008. Karena Indonesia termasuk negara yang telah meratifikasi TRIPs, maka pada dasarnya konsep hak cipta yang diharapkan $\mathrm{CCi}$ sama dengan yang ada di Indonesia.

Berdasarkan Undang-Undang Nomor 11 Tahun 2008 tentang

${ }^{27}$ Lawrence Lessig, Budaya Bebas, Op., Cit., h. 227

${ }^{28} \mathrm{http}$ ://creativecommons.or.id/2011/10/apakah-creative-commons-itu-dan-apakegiatannya/

${ }^{29} \mathrm{http}: / / w w w . w i k i m e d i a . w e b . i d$ 
Informasi dan Transaksi Elektronik (selanjutnya disebut UU ITE), kegiatan yang dilaksanakan oleh creative commons adalah kegiatan penyelenggaran sistem elektronik, sehingga selain tunduk dengan Undang-Undang Hak Cipta, kegiatan creative commons juga wajib mengikuti UU ITE. ${ }^{30}$ Dalam Pasal 1 ayat (5) UU ITE dikatakan bahwa sistem elektronik adalah serangkaian perangkat dan prosedur elektronik yang berfungsi mempersiapkan, mengumpulkan, mengolah, menganalisis, menyimpan, menampilkan, mengumumkan, mengirimkan dan/atau menyebarkan informasi elektronik. Oleh karena itu, kegiatan creative commons tersebut harus tunduk pada UU ITE. selanjutnya dalam Pasal 15 diatur bahwa:

1) Setiap penyelenggara sistem elektronik harus mengelenggarakan sistem elektronik secara andal dan aman serta bertanggung jawab terhadap beroperasinya sistem elektronik sebagai mestinya.

2) Penyelenggara sistem elektronik bertanggung jawab terhadap penyelenggaraan sistem elektroniknya.

3) Ketentuan sebagaimana dimaksud pada ayat (2) tidak berlaku dalam hal dapat dibuktikan terjadinya keadaan memaksa, kesalahan, dan/atau pihak pengguna sistem elektronik.

Sehubungan dengan ketentuan diatas, penting untuk diingat bahwa sebagai penyelenggara sistem elektronik, creative commons hanya menyediakan perjanjian lisensi secara gratis, bukan sebagai sebuah kantor advokat yang memberikan layanan konsultasi hukum ataupun sebuah lembaga yang melakukan registrasi karya cipta (seperti yang dilakukan oleh Direktorat Hak pada Dirjen HKI), sehingga tidak bertanggung jawab atas konten yang diunggah. Atas perjanjian lisensi tersebut, creative commons telah melakukan integrasi atas metadata perjanjian lisensi yang digunakan untuk karya yang dipublikasikan secara online maupun data atas perjanjian lisensi yang digunakan untuk karya yang dipublikasikan secara offline, sehingga karya-karya yang menggunakan perjanjian lisensi creative commons dapat diidentifikasi melalu mesin pencari (search engine) atau media online yang terafiliasi dengan creative commons. Sehingga dengan demikian penyelenggaraan sistem elektronik yang dilakukan creative commons dalam hal ini telah melaksanakan ketentuan Pasal 16 Ayat (1) UU ITE, yaitu:

Sepanjang tidak ditentukan lain oleh Undang-Undang tersendiri, setiap penyelenggara sistem elektronik wajib mengoperasikan sistem elektronik yang memenuhi persyaratan minimum sebagai berikut:

1) Dapat menampilkan kembali informasi elektronik dan/atau

\footnotetext{
${ }^{30}$ Rusdiansyah, "Membangun Prototype Sistem Informasi Arsip Elektronik Surat Perjanjian Kerjasama Pada Business Support Departement." Jurnal Pilar Nusa Mandiri Volume 14 Nomor 2, Tahun 2018, h. 157-162
} 
dokumen elektronik secara utuh sesuai dengan masa retensi yang ditetapkan peraturan perundang-undangan.

2) Dapat melindungi ketersediaan, keutuhan, keotentikan, kerahasiaan dan keteraksesan informasi elektronik dalam penyelenggaraan sistem elektronik tersebut.

3) Dapat beroperasi sesuai dengan prosedur atau petunjuk dalam penyelenggaraan sistem elektronik tersebut.

4) Dilengkapi dengan prosedur atau petunjuk yang diumumkan dengan bahasa, informasi atau simbol yang dapat dipahami oleh pihak yang bersangkutan dengan penyelenggaraan sistem elektronik tersebut, dan

5) Memiliki mekanisme yang berkelanjutan untuk menjaga kebaruan, kejelasan dan kebertanggung jawaban prosedur atau petunjuk.

Sehubungan dengan kegiatan creative commons, maka sebagai sebuah provider creative commons harus dapat melaksanakan kegiatan penyelenggaraan sistem elektronik tersebut secara bertanggung jawab, sehingga tidak hanya sekedar menyediakan perjanjian lisensi secara gratis melalui internet saja. Dalam Directive 2000/31/EC of the European Parliament and of the Council of 8 June 2000 on Certain Legas Aspect of Information society Service, in Particular Electronic Commerce, In the internal market, Section 4 Article 12 mengenai "Mere Conduit" dikatakan: ${ }^{31}$

1) Where an information society service is provide that consist of the transmission in a communication network of information provide by a recipient of the service, or the provision of access to a communication network, member states shall ensure that the service provider is not liable for the information transmitted, on condition that the provider:

i. Does not initiate the transmission;

ii. $\quad$ Does not select the receiver of the transmission; and

iii. Does not select or modify the information contained in the transmission.

2) The acts of transmission and of provision of access referred to in paragraph 1 include the automatic, intermediate and transient storage of the information transmitted in so far as this takes place for the sole purpose of carrying out the transmission in the communication network, and provide that the information is not

${ }^{31}$ The European Parliament and of the Council of 8 June 2000 on Certain Legal Aspects of information society service, in particular electronic commerce, in the internal market, http://www.tourimlaw.eu/documents/tourism_legislation/EU_8june2000_uk.pdf, 
stored for ant period longer than is reasonably necessary for the transmission.

3) This article shall not affect the possibility for a court or administrative authority, in accordance with member state legal system, of requiring the service provider to terminate or prevent an infringement.

Sehubungan dengan mere conduit diatas, kegiatan creative commons sebagai provider tidak dapat dimintakan pertanggung jawaban atas konten yang menggunakan lisensi creative commons karena kegiatan utama creative commons hanyalah meyediakan perjanjian lisensi dan melakukan integrasi data atas perjanjian lisensi yang digunakan sehingga tidak berhubungan dengan konten yang menjadikan objek perjanjian lisensi.

\section{KESIMPULAN}

Creative Commons License memberikan kemudahan bagi seseorang untuk menyatakan sikap atas hasil karyanya. Seseorang yang mempunyai karya cipta dapat mendaftarkan karya ciptanya tersebut ke lisensi Creative Commons dan diberikan suatu simbol oleh lisensi Creative Commons simbol-simbol itu berlaku dan dipahami secara universal di negara-negara yang menerapkannya. Sama seperti rambu-rambu lalu lintas yang pada umumnya sama di berbagai negara dan dipahami secara universal. Lisensi creative commons meningkatkan transparansi dan kepastian hukum bagi para pengguna ciptaan dan pemegang hak cipta. Creative commons bukanlah jalan alternatif dari hukum hak cipta, melainkan bekerja berdampingan dengan hukum hak cipta dan mampu membuat pencipta/pemegang hak cipta memodifikasi haknya ke dalam keadaan yang paling sesuai dengan kebutuhan. Oleh karena hak eksklusif hanya dilisensikan sebagian dan di bawah syarat-syarat tertentu, pengguna yang melanggar lisensi, berarti juga melanggar Undang-Undang Hak Cipta.Sistem hukum hak cipta yang demikian telah membentuk "budaya izin", yang berarti budaya lisensi creative commons, dimana untuk beberapa hal kita tidak perlu menghubungi pemilik hak cipta terlebih dahulu sebelum mengunakan karyanya tersebut.Hukum pun menjadi efisien dan biaya transaksi yang dibutuhkan dalam "budaya izin" tidaklah mahal bahkan geratis serta creative commons juga dapat meningkatkan visibilitas pilihan hak cipta di internet yang akan membuat orang dapat dengan mudah menemukan hak cipta karya yang mereka gunakan.Di Indonesia lisensi Creative Commons penggunaannya dimungkinkan menurut Pasal 9 UU Hak Cipta. Dalam pasal tersebut, disebutkan bahwa Pemegang Hak berdasarkan Pasal 81 UU Hak Cipta, yaitu izin untuk mengumumkan dan/atau Cipta berhak memberikan lisensi kepada pihak lain berdasarkan perjanjian lisensi 
untuk melaksanakan perbuatan sebagaimana dimaksud dalam Pasal memperbanyak ciptaannya/produk hak terkaitnya dengan persyaratan tertentu. Berdasarkan Undang-Undang Nomor 11 Tahun 2008 tentang Informasi dan Transaksi Elektronik kegiatan yang dilaksanakan oleh creative commons adalah kegiatan penyelenggaran sistem elektronik, sehingga selain tunduk dengan Undang-Undang Hak Cipta, kegiatan creative commons juga wajib mengikuti UU ITE.

\section{DAFTAR PUSTAKA}

\section{Buku}

Guibault, Lucie dan Angelopoulos, Christina, Ed., 2011, Open Content Licensing: from Theory to Practice, Amsterdam: Amsterdam University Press. , 2004, Budaya Bebas: Bagaimana Media Besar Memakai Teknologi dan Hukum untuk Membatasi Budaya dan Mengontrol Kreativitas, Yogyakarta: KUNCI Cultural Studies Center.

Lessig, Lawrence, 2001, The Future of Ideas, New York: Random House. Makarim, Edmon, 2004, Kompilasi Hukum Telematika, Jakarta: P.T. Raja Grafindo Persada.

Natanel, Neil Weinstock, 2008, Copyright's Paradox, New York: Oxford University Press.

Ramli, M. Ahmad, 2006, Cyber Law dan HAKI Dalam Sistem Hukum Indonesia, Bandung: PT Refika Aditama.

Shapiro, Carl dan Varian, Han Ronald, 1999, A Strategic Guide to the Network Economy, Boston: Harvard Business School Press.

Soekanto, Soerjono, 2006, Penelitian Hukum Normatif, Jakarta: Rajawali Pers.

Wijaya, Gunawan, 2011, Lisensi (Seri Hukum Bisnis), Jakarta: Raja Grafindo Persada.

\section{Jurnal}

Kilanta, Devega R., "Penegakan Hukum terhadap Hak Cipta Berdasarkan Undang-Undang Nomor 28 Tahun 2014 tentang Hak Cipta." Lex Crimen, Volume 6 Nomor 3 Tahun 2017

Raharjo, Riko Sulung, M. Khoidin, and Ermansyah, Fahamsyah. "Perlindungan Hukum terhadap Pencipta atas Pencatatan Suatu Ciptaan yang Sama." Jurnal Lentera Hukum, Volume 5 Nomor 3 Tahun 2018, h. 437-456.

Rusdiansyah, "Membangun Prototype Sistem Informasi Arsip Elektronik Surat Perjanjian Kerjasama Pada Business Support Departement." Jurnal Pilar Nusa Mandiri Volume 14 Nomor 2, Tahun 2018, h. 157-162 
Sulistianingsih, Dewi dan Prabowo, Muhammad Shidqon, "Problematik Dan Karakteristik Penyelesaian Sengketa Kekayaan Intelektual Melalui Badan Arbitrase Nasional Indonesia." QISTIE: Jurnal Ilmu Hukum, Volume 12 Nomor 2, Tahun 2019, h. 166-177

\section{Makalah}

Gunawan, Aditia, "Creative Commons: Penerapannya di Indonesia", Konferensi Perpustakaan Digital Indonesia, Jakarta, Makalah 2013

Putro, Kusuma Prasetyo, "Creative Commons Lisence sebagai Alternatif Perlindungan Karya Cipta Musik di Era Digital”. Makalah.

\section{Internet}

Crosby, Alexandra dan Thajib, Ferdiansyah, "A Culture of Sharing," Inside Indonesia, 2011, http://www.insideindonesia.org/weeklyarticles/a-culture-of-sharing http://creativecommons.org/about https://creativecommons.org/licenses/by-nc-sa/4.0/legalcode.id http://creativecommons.or.id/2011/10/apakah-creative-commons-itu-danapa-kegiatannya/

http://www.wikimedia.web.id

Lessig, Lawrence CC in Review: Lawrence Lessig on Supporting the Commons http//creativecommons.org/weblog/entry/5561

"Some Rights Reserved": Building a Layer Reasonable Copyright http//creativecommons.org/History

The European Parliament and of the Council of 8 June 2000 on Certain Legal Aspects of information society service, in particular electronic commerce, in the internal market, http://www.tourimlaw.eu/documents/tourism_legislation/EU_8june2 000_uk.pdf, 